\title{
INFLUENCE OF RICE STRAW COMPOST COMBINED WITH MINERAL NITROGEN FERTILIZER ON EGYPTIAN HYBRID RICE 1 PRODUCTIVITY AND SOME RICE PESTS
}

\author{
Elkhoby, W. M.
}

Rice Research Department, Field Crops Research Institute, Agricultural Research Center, Egypt.

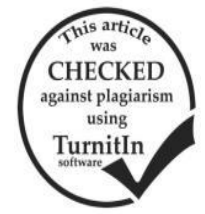

\begin{abstract}
The Present study was designed to investigate the effect of rice straw compost, recommended mineral nitrogen fertilizers and their combinations on growth, yield and yield attributes of Egyptian hybrid rice 1 variety (EHR1) as well as incidence of white head, leaf miner and sheath rot disease in hybrid rice and its productivity. The trail was carried out at the experimental farm of Sakha Agriculture Research Station as part of research activity of Rice Research Department, Sakha, Kafr El-Sheikh during 2013 and 2014 seasons. The studied treatments were performed as follows: control, $69 \mathrm{~kg} \mathrm{~N}_{\mathrm{ged}}{ }^{-1}, 2.5 \mathrm{t}$ rice straw compost (RSC), $23 \mathrm{~kg} \mathrm{~N}$ fed $^{-1}+2.5 \mathrm{t} \mathrm{RSC}$ and $46 \mathrm{~kg} \mathrm{~N} f e d^{-1}+2.5 \mathrm{t} \mathrm{RSC} \mathrm{fed}^{-1}$. The infestations of stem borer and leaf miner insects as well as sheath rot disease were measured.

Results indicated that growth yield and yield attributing components were significantly influenced by varying fertilizer treatments, either rice straw compost or mineral nitrogen or their combinations in both seasons. Both treatments of $69 \mathrm{~kg} \mathrm{~N}^{-1} \mathrm{~d}^{-1}$ and $46 \mathrm{~kg} \mathrm{~N}$ fed $^{-1}+2.5 \mathrm{t} \mathrm{RSC} \mathrm{fed}^{-1}$ were comparatively better in almost studied characteristics indicating the possibility to reduce the mineral nitrogen by one third on the recommended rate. The economic values have been estimated. Rice fertilized with mineral nitrogen at the recommendation rate had the highest level of white heads.

The lowest values of white head \% were recorded when rice plants were fertilized with $2.5 \mathrm{RSC} \mathrm{t}$ fed $^{-1}$ in both seasons. The applications of sole composted rice straw reduced sheath rot disease infection percentage when applied alone or mixed with $23 \mathrm{~kg} \mathrm{~N} \mathrm{fed}^{-1}$. The treatment of $69 \mathrm{~kg} \mathrm{~N} \mathrm{fed}^{-1}$ gave the highest values of net return followed by the treatment of $46 \mathrm{~kg} \mathrm{~N}^{-1}+$ $2.5 \mathrm{t}$ RSC in both seasons of study.

To sum up, from the point of view of yield, economic and soil sustainability as well as environment and pest management, the treatment of $46 \mathrm{~kg} \mathrm{~N}$ fed $^{-1}+2.5 \mathrm{t}$ RSC could be recommended.
\end{abstract}

Keywords: Compost, Rice field, hybrid rice, yield, white head, and sheath rot disease

\section{INTRODUCTION}

Rice (Oryza sativa L.) is considered as one of two most important cereal crops in the world. In Egypt, it contributes more than 20 percent of the cereal consumption (Ministry of Agriculture and land Reclamation, 2012)

Organic fertilizer is a system which primarily aims at eliminating environmental pollution and develop a more profitable and sustainable farming (YungYu, 2005; Heckman, 2006).

Rice straw left in the field after harvesting is generally burnt by the farmers to facilitate soil preparation prior to the next crop. Burning causes loss of beneficial arthropods, micro and macro fauna, organic matter and plant nutrient and may lead to environmental pollution. So instead of burning of rice straw, there are other economical ways to get rid of it, one of the ways is by making compost and incorporating in it the soil as a source of organic matter (Gotoh et al., 1984).

Usually, rice growers are getting worried about pests infestation in rice crop, regardless of economic losses. Thus, they use excessive insecticide applications with over doses to find their fields clear from any damage. These practices affect negatively the populations of natural enemies (Croft, 1990 and Pekar, 2012). It was pointed out that agriculture without insecticides, as in case of organic farming, has been considered to keep the natural balance, as well as preserve the native diversity

Buri et al. (2004) in an experiment with poultry manure, cattle manure, and rice husks, applied solely or in combination with mineral fertilizer (using urea or sulphate of ammonia as $\mathrm{N}$ source) found that a combination of a half rate of organic fertilizer and a half rate of mineral fertilizer significantly contributed to the growth and yield of rice. Similarly, Nyalemegbe et al. (2009) found that combining $10 \mathrm{t} \mathrm{ha}^{-1}$ of cow dung with $45 \mathrm{~kg} \mathrm{~N} \mathrm{ha}^{-1}$ urea, or $10 \mathrm{tha}^{-1}$ poultry manure with 60 $\mathrm{kg} \mathrm{N} \mathrm{ha}^{-1}$, gave higher yields comparable to those under high levels of nitrogen application (i.e., 90 and $120 \mathrm{~kg}$ $\mathrm{N} \mathrm{ha}^{-1}$ ) applied solely. Nyalemegbe et al. (20090 found that rice straw surpassed poultry manure and cow dung in the Vertisols of the Accra Plains of Ghana. Man et al. (2009) reported that chemical fertilizer inputs can be reduced by 20 to $60 \%$ from the present recommended application rate by using rice straw manure $\left(6 \mathrm{t} \mathrm{ha}^{-1}\right)$ without decreasing rice yield and yield components, while keeping high soil fertility level and high availability of nutrients. Under salinized clay soils, Zayed el al. (2013) found that application of $5 \mathrm{tha}^{-1}$ rice straw compost $+110 \mathrm{~kg} \mathrm{~N}^{-1}$ could be recommended for use with salinity soil in which it reduced the chemical $\mathrm{N}$ fertilizer by one third. Also, they reported that rice compost surpassed the other organic sources such as farmyard manure since it enriched soil, increased nutrient availability, improved soil physical properties and net return of rice production per unit area. Gareib et al. (2015) and Metwaly (2015) found that $10 \mathrm{Kg} \mathrm{N} \mathrm{ha}^{-1}, 7$ ton compost ha ${ }^{-1}$ and $169 \mathrm{~kg} \mathrm{~N} \mathrm{ha}^{-1}$ were comparable regarding rice yield.

The rice leaf miner, Hydrellia prosternalis has recently become an important insect pest in rice fields in Egypt (Sherif et al., 2005) as the larvae damage the rice plants by mining their leaves. Some authors claim no reduction in yield even when rice plants are severely damaged (Nurullah, 1979). Sheath rot, caused by Sarocdadium oryzae (Sawada) Gams and Hawksw has gained the status of a major disease of rice and yield loss varying from 9.6 to $85 \%$ (Thapak et al., 2003). The major feature of rice sheath rot disease is rotting and 
discoloration of the sheath, leading to chaffiness and sterility of resulting grains according to Ou (1985). For many years, rice sheath rot was considered as a minor and geographically limited disease. Crop intensification practices such as increased plant density, a high rate of nitrogen fertilizers and the use of semi-dwarf and photoperiod-insensitive cultivars, favor the susceptibility of rice to the sheath rot disease. The Egyptian Hybrid 1 is the most cultivars susceptible to the sheath rot disease according to Mona (2012).

This investigation was performed to study the optimal combinations of organic fertilizers in the terms of rice straw compost (RSC) and mineral nitrogen for sustainable rice production under Egyptian agronomic conditions. Furthermore, getting the full yield potentiality of hybrid rice is deemed as second aim for the current investigation.

\section{MATERIALS AND METHODS}

Two field experiments were conducted at the Farm of Sakha Agricultural Research Station, KafrElsheikh, Egypt, during 2013 and 2014 rice growing seasons. The investigation aimed to study the impact of five soil fertility treatments on rice plant growth, yield attributes, grain yield, and white head infestation, as well as on leaf miner infestation and sheath rot disease. The treatments were as follows :

(i) control

(ii) $69 \mathrm{~kg} \mathrm{~N}^{-1} \mathrm{fed}^{-1}$ (100\% recommended nitrogen)

(iii) $2.5 \mathrm{t}$ of rice straw compost (RSC)

(iv) $2.5 \mathrm{t}$ of rice straw compost (RSC) $+23 \mathrm{~kg} \mathrm{~N}$ fed $^{-1}$ (v) $2.5 \mathrm{t} \mathrm{fed}^{-1}$ of rice straw compost (RSC) $+46 \mathrm{~kg} \mathrm{~N}$ fed-1

The rice compost straw (RSC) was merely mixed with the dry soil 15 days before transplanting. Urea $(46 \% \mathrm{~N})$ was applied as specified per treatment in three equal doses at 15, 30 and 45 days after transplanting (DAT). The rice cultivar used in this experiment was Egyptian Hybrid rice 1. The experiment was laid out in a randomized complete block design with four replications. The plot size was $10 \mathrm{~m}^{2}$ each $(5.0 \times 2.0 \mathrm{~m})$. Phosphorous fertilizer in the form of calcium superphosphate at the rate of $15 \mathrm{~kg} \mathrm{P}_{2} \mathrm{O}_{5} \mathrm{fed}^{-1}$ was applied basally and merely incorporated in the soil. Potassium in the form of potassium sulphate at the rate of $24 \mathrm{~kg} \mathrm{k}_{2} \mathrm{O}$ fed $^{-1}$ were applied in to equal doses, half as basal and half top dressing at 30 day after transplanting.

The treatments were transplanted with 2seedling/hill and spaced in $20 \mathrm{~cm}$ in row and $20 \mathrm{~cm}$ in hill. The rest of recommendation package of rice were precisely followed according to rice research program, ministry of agriculture, Egypt.

Soil samples were taken from the experimental site at the beginning of the experiment for initial analysis. The experimental site and treatment plots were fixed during the two years of study. Prior to the rice study, wheat was cultivated in the plot in a wheat-rice cropping system to assess any effects over time. Table 1 presents the initial soil chemical analysis from the experimental site before transplanting in 2013 and 2014. Table 2 shows the chemical properties of the rice straw compost used in the experiment.

Table 1: Soil chemical analysis of experimental site prior to transplanting, Sakha Agricultural Research Station farm, 2013 and 2014

\begin{tabular}{|c|c|c|c|c|c|c|c|c|c|c|c|c|c|}
\hline \multirow[t]{2}{*}{ seasons } & \multirow{2}{*}{$\begin{array}{l}\text { OM } \\
(\%)\end{array}$} & \multirow{2}{*}{$\begin{array}{c}\text { ECe } \\
\left(\mathrm{dS} \mathrm{m}^{-1}\right)\end{array}$} & \multirow[t]{2}{*}{ pH } & $\mathrm{Na}^{+1}$ & $\begin{array}{l}\mathrm{Ca}^{+2}+ \\
\mathrm{Mg}^{+2} \\
\end{array}$ & $\mathrm{~K}^{+1}$ & $\mathrm{HCO}^{-}$ & Cl & $\mathrm{SO}_{4}{ }^{-2}$ & \multirow{2}{*}{$\begin{array}{c}\mathbf{N} \\
(\%)\end{array}$} & \multicolumn{3}{|c|}{$\begin{array}{c}\text { Available } \\
\text { (ppm) }\end{array}$} \\
\hline & & & & \multicolumn{6}{|c|}{$\left(\right.$ meg l l $\left.^{-1}\right)$} & & $\mathbf{P}$ & $\mathbf{K}$ & $\mathrm{Zn}$ \\
\hline 2013 & 1.90 & 2.5 & 8.13 & 16 & 9 & 0.31 & \begin{tabular}{|l|}
5.4 \\
\end{tabular} & 11 & 8.6 & 0.15 & 12 & 340 & 1 \\
\hline \begin{tabular}{|l|}
2014 \\
\end{tabular} & 2.1 & 2.1 & 8.23 & 15 & 7 & 0.29 & 5.0 & 10 & 6 & 0.2 & 13 & 320 & 1.1 \\
\hline
\end{tabular}

Table 2: Chemical analysis of rice straw compost used in the rice experiments at Sakha Agricultural Research Station farm in Kafr Elsheikh

\begin{tabular}{|l|c|c|c|c|c|c|c|c|}
\hline Type & $\begin{array}{c}\mathbf{C} \\
(\%)\end{array}$ & $\begin{array}{c}\mathbf{N} \\
(\%)\end{array}$ & $\begin{array}{c}\text { C:N } \\
\text { ratio }\end{array}$ & $\begin{array}{c}\mathbf{P} \\
(\%)\end{array}$ & $\begin{array}{c}\mathbf{K} \\
(\%)\end{array}$ & $\begin{array}{c}\text { OM } \\
(\%)\end{array}$ & $\begin{array}{c}\text { Fe } \\
(\%)\end{array}$ & $\begin{array}{c}\mathbf{Z n} \\
(\%)\end{array}$ \\
\hline Rice straw compost & 34.3 & 1.82 & 18.85 & 0.78 & 1.93 & 47 & 0.046 & 0.005 \\
\hline
\end{tabular}

At panicle initiation and late booting stages, five hills were randomly selected from the third row of each plot and transferred to the laboratory to determine plant height $\mathrm{cm}$, tillers number hill ${ }^{-1}$, chlorophyll content and dry matter content according to Yoshida et al, (1976). Total chlorophyll content was measured on the top fully expanded three rice leaves using chlorophyll meter (SPAD502 model).

At harvest stage, five hills were randomly chosen to determine plant height, number of tillers, dry matter $g$ hill-, panicle length, number of panicles hill ${ }^{-1}$, panicle weight $g$ and number of filled grains panicle ${ }^{-1}$ and 1000 grain weight. Plants of sex inner rows out of 10 rows of each plot were harvested and transferred to a threshing area for air-drying. Five days later, plants were threshed and weighed. Weights were adjusted to $14 \%$ moisture content. Economic parameters were calculated, namely, total production cost, variable cost, fixed and overhead costs, and gross and net returns. The data of each season were subjected to statistical analysis of variance and mean separate tests by LSD at the 5\% level of significance according to Gomez and Gomez (1984). Analysis of variance was adopted, and means were compared using Duncan's Multiple Range Test (1955).

\section{Stem borer measurement:}

The rice stem borer infestation was evaluated as white head symptom. To calculate the percentage of white heads, a sample of 25 hills was taken and cut at soil surface. Number of total tillers in the plant sample was recorded. The tillers having white head were counted. Percentage of white head was calculated as multiplied by 100 and divided by total number of tillers in the taken plant sample. 
White head $(\%)=\frac{\text { No. of white head tillers }}{\text { No. of tillers }} \times 100$

Leaf minor measurement:

Twenty days after transplanting, all rice plots were examined to count number of infested leaves and number of insect mines per 100 rice leaves. Parameters used to express severity of infestation were the percentage of infested rice leaves and number of mines/100 rice leaves

Sheath rots disease estimation:

At harvesting stage typical sheath rot symptoms were was assessed according to (Thapak et al., 2003) as following :

Infection $(\%)=\frac{\text { No. of infected plants }}{\text { No. of total plants }} \times 100$

\section{RESULTS AND DISCUSSION}

A. Agronomic characteristics:

A.1 plant growth parameters :

Plant growth characteristics, plant height, tillers number, chlorophyll content and dry matter content were significantly affected by different tested fertilizer treatments at different growth stages. Data in Tables 3, 4 and 5 showed that plant height was significantly affected by various fertilizer treatments. The results showed that all studied fertilizer treatments caused significant increases in plant height over control (without nitrogen application). The couple treatments of $46 \mathrm{~kg} \mathrm{~N} f e d^{-1}+2.5 \mathrm{t} \mathrm{RSC} \mathrm{fed}^{-1}$ and $69 \mathrm{~kg} \mathrm{~N}$ fed $^{-1}$ gave comparable higher values of plant height at different growth stages than of $23 \mathrm{~kg} \mathrm{~N} \mathrm{fed}+2.5 \mathrm{t} \mathrm{RSC} \mathrm{fed}^{-1}$. While, the application of $2.5 \mathrm{t}$ composted rice straw fed ${ }^{-}$ 1 gave the shortest statures at all growth stages irrespective control treatment. Nitrogen fertilization has favorable effect on improving rice growth, photosynthesis, and metabolism and assimilates production leading to improving plant height as a result of raising cell elongation. Furthermore, nitrogen fertilizer raised plant nitrogen content, which resulted in high content of some growth regulator such as IAA which increased cell elongation and division. These results are similar to the findings of Metwally et al. (2011), zayed et al. (2013), Gareib et al (2015) and Metwaly (2015).

Table 3: Some Rice growth characteristics of EHR1at panicle initiation stage as affected by rice straw compost, mineral $N$ fertilizers and their combination during 2013 and 2014 seasons.

\begin{tabular}{|l|c|c|c|c|c|c|c|c|}
\hline \multirow{2}{*}{ Treatments } & \multicolumn{2}{|c|}{$\begin{array}{c}\text { Plant height } \\
\text { cm }\end{array}$} & \multicolumn{2}{c|}{$\begin{array}{c}\text { Number of } \\
\text { tillers hill }\end{array}$} & \multicolumn{2}{c|}{$\begin{array}{c}\text { Chlorophyll } \\
\text { content (SPAD) }^{-1}\end{array}$} & $\begin{array}{c}\text { Dry matter } \\
\text { accumulation g hill }^{-1}\end{array}$ \\
\cline { 2 - 9 } & $\mathbf{2 0 1 3}$ & $\mathbf{2 0 1 4}$ & $\mathbf{2 0 1 3}$ & $\mathbf{2 0 1 4}$ & $\mathbf{2 0 1 3}$ & $\mathbf{2 0 1 4}$ & $\mathbf{2 0 1 3}$ & $\mathbf{2 0 1 4}$ \\
\hline Control & $58.00 \mathrm{~d}$ & $57.33 \mathrm{~d}$ & $21.70 \mathrm{c}$ & $20.67 \mathrm{c}$ & $33.41 \mathrm{~d}$ & $31.83 \mathrm{c}$ & $24.26 \mathrm{e}$ & $22.86 \mathrm{~d}$ \\
\hline $69 \mathrm{~kg} \mathrm{~N} \mathrm{fed-1}$ & $85.50 \mathrm{a}$ & $83.85 \mathrm{a}$ & $33.75 \mathrm{a}$ & $31.91 \mathrm{a}$ & $44.76 \mathrm{a}$ & $42.00 \mathrm{a}$ & $47.34 \mathrm{~b}$ & $44.87 \mathrm{~b}$ \\
\hline $2.5 \mathrm{t} \mathrm{RSC}^{*}$ fed-1 & $62.49 \mathrm{c}$ & $63.55 \mathrm{c}$ & $27.87 \mathrm{~b}$ & $26.56 \mathrm{~b}$ & $39.18 \mathrm{~b}$ & $38.96 \mathrm{ab}$ & $38.87 \mathrm{~d}$ & $36.33 \mathrm{c}$ \\
\hline $23 \mathrm{Kg} \mathrm{N} \mathrm{fed-1} \mathrm{+} \mathrm{2.5} \mathrm{t} \mathrm{RSC} \mathrm{fed-1}$ & $72.15 \mathrm{~b}$ & $77.22 \mathrm{~b}$ & $29.16 \mathrm{~b}$ & $28.9 \mathrm{ab}$ & $37.19 \mathrm{c}$ & $36.34 \mathrm{bc}$ & $43.21 \mathrm{c}$ & $42.61 \mathrm{~b}$ \\
\hline $46 \mathrm{~kg} \mathrm{~N}$ fed-1+2.5 t RSCfed-1 & $88.23 \mathrm{a}$ & $86.18 \mathrm{a}$ & $30.69 \mathrm{ab}$ & $28.17 \mathrm{ab}$ & $41.78 \mathrm{ab}$ & $37.98 \mathrm{ab}$ & $58.64 \mathrm{a}$ & $57.86 \mathrm{a}$ \\
\hline
\end{tabular}

RSC $^{*}=$ Rice straw compost, Means followed by the same letter are not significantly different at the $5 \%$ level.

As for number of tillers hill ${ }^{-1}$, the highest value was observed with $69 \mathrm{~kg} \mathrm{~N} \mathrm{fed}{ }^{-1}$, without any significant differences with those of $46 \mathrm{~kg} \mathrm{~N}$ ferd $^{-1}+2.5$ RSC fed ${ }^{-1}$. The rest of treatment showed that the same low and high pattern of plant height regarding tillers number (Table 5). Number of tillers $\mathrm{m}^{2}$ as a result of nitrogen and compost might be due to the more availability of nitrogen that plays a vital role in cell division and tiller buds formation. These results are in accordance to the findings of Zayed et al., (2013).

Tables 3 and 4 showed that chlorophyll content increased significantly by application of various fertilizer treatments during 2013 and 2014 seasons. In both seasons, at all studied growth stage, the application of $69 \mathrm{~kg} \mathrm{~N}$ fed $^{-1}$ produced the highest chlorophyll content without significant differences with application of $46 \mathrm{~kg}$ late booting growth stage, application of $69 \mathrm{~kg}$ $\mathrm{N}$ fed $^{-1}$ exhibited the highest values of chlorophyll content without significant differences with $46 \mathrm{~kg} \mathrm{~N}$ fed-1 + 2.5 t RSC fed ${ }^{-1}$. These results proved that chlorophyll content increased by elevating nitrogen fertilizer combined with RSC that attributed to the role of nitrogen in enhancing plant pigment formation resulted in higher chlorophyll content. Zayed etl al., (2013) came to similar results.

Table 4: Some Rice growth characteristics of EHR1at late booting stage as affected by rice straw compost, mineral $N$ fertilizers and their combinations during 2013 and 2014 seasons.

\begin{tabular}{|l|c|c|c|c|c|c|c|c|}
\hline \multirow{2}{*}{ Treatments } & \multicolumn{2}{|c|}{$\begin{array}{c}\text { Plant height } \\
\text { cm }\end{array}$} & \multicolumn{2}{c|}{$\begin{array}{c}\text { Number of } \\
\text { tillers hill }\end{array}$} & \multicolumn{2}{c|}{$\begin{array}{c}\text { Chlorophyll } \\
\text { content (SPAD) }\end{array}$} & \multicolumn{2}{c|}{$\begin{array}{c}\text { Dry matter } \\
\text { Accumulation g hill }\end{array}$} \\
\cline { 2 - 9 } & $\mathbf{2 0 1 3}$ & $\mathbf{2 0 1 4}$ & $\mathbf{2 0 1 3}$ & $\mathbf{2 0 1 4}$ & $\mathbf{2 0 1 3}$ & $\mathbf{2 0 1 4}$ & $\mathbf{2 0 1 3}$ & $\mathbf{2 0 1 4}$ \\
\hline Control & $87.93 \mathrm{c}$ & $86.78 \mathrm{~b}$ & $18.21 \mathrm{e}$ & $17.98 \mathrm{~d}$ & $37.68 \mathrm{~d}$ & $36.46 \mathrm{~d}$ & $66.57 \mathrm{~d}$ & $63.53 \mathrm{~d}$ \\
\hline $69 \mathrm{~kg} \mathrm{~N} \mathrm{fed-1}^{-1}$ & $98.98 \mathrm{a}$ & $98.20 \mathrm{a}$ & $30.19 \mathrm{a}$ & $29.74 \mathrm{a}$ & $44.96 \mathrm{a}$ & $46.81 \mathrm{a}$ & $166.2 \mathrm{a}$ & $163.0 \mathrm{a}$ \\
\hline $2.5 \mathrm{RSC}^{*} \mathrm{fed}^{-1}$ & $94.66 \mathrm{~b}$ & $94.78 \mathrm{a}$ & $22.50 \mathrm{~d}$ & $20.15 \mathrm{c}$ & $40.65 \mathrm{~b}$ & $40.65 \mathrm{~b}$ & $119.0 \mathrm{c}$ & $116.9 \mathrm{c}$ \\
\hline $23 \mathrm{Kg} \mathrm{N} \mathrm{fed}^{-1}+2.5 \mathrm{t} \mathrm{RSC} \mathrm{fed}^{-1}$ & $96.11 \mathrm{~b}$ & $93.45 \mathrm{a}$ & $25.63 \mathrm{c}$ & $25.01 \mathrm{~b}$ & $41.89 \mathrm{~b}$ & $41.93 \mathrm{~b}$ & $148.4 \mathrm{~b}$ & $153.8 \mathrm{~b}$ \\
\hline $46 \mathrm{~kg} \mathrm{~N} \mathrm{fed}^{-1}+2.5 \mathrm{RSCfed}^{-1}$ & $98.95 \mathrm{a}$ & $97.87 \mathrm{a}$ & $28.38 \mathrm{ab}$ & $27.19 \mathrm{a}$ & $44.86 \mathrm{a}$ & $45.11 \mathrm{a}$ & $168.2 \mathrm{a}$ & $165.2 \mathrm{a}$ \\
\hline
\end{tabular}

$\mathbf{R S C}^{*}=$ Rice straw compost, Means followed by the same letter are not significantly at the $5 \%$ level. 
Table 5: Some Rice growth characteristics of EHR1at harvest stage as affected by rice straw compost, mineral $\mathrm{N}$ fertilizer and their combinations during 2013 and 2014 seasons.

\begin{tabular}{|l|c|c|c|c|c|c|}
\hline \multirow{2}{*}{ Treatments } & \multicolumn{2}{|c|}{$\begin{array}{c}\text { Plant height } \\
\text { cm }\end{array}$} & \multicolumn{2}{c|}{$\begin{array}{c}\text { Number of tillers } \\
\text { hill }^{-1}\end{array}$} & $\begin{array}{c}\text { Dry matter accumulation g } \\
\text { hill }^{-1}\end{array}$ \\
\cline { 2 - 7 } & $\mathbf{2 0 1 3}$ & $\mathbf{2 0 1 4}$ & $\mathbf{2 0 1 3}$ & $\mathbf{2 0 1 4}$ & $\mathbf{2 0 1 3}$ & $\mathbf{2 0 1 4}$ \\
\hline Control & $89.00 \mathrm{c}$ & $87.51 \mathrm{~d}$ & $15.98 \mathrm{~d}$ & $15.78 \mathrm{c}$ & $88.35 \mathrm{~d}$ & $87.45 \mathrm{~d}$ \\
\hline $69 \mathrm{~kg} \mathrm{~N} \mathrm{fed}^{-1}$ & $103.1 \mathrm{a}$ & $105.5 \mathrm{a}$ & $27.76 \mathrm{a}$ & $27.44 \mathrm{a}$ & $187.0 \mathrm{a}$ & $190.2 \mathrm{a}$ \\
\hline $2.5 \mathrm{RSC}^{*} \mathrm{fed}^{-1}$ & $95.33 \mathrm{~b}$ & $94.12 \mathrm{c}$ & $20.13 \mathrm{c}$ & $18.88 \mathrm{bc}$ & $133.3 \mathrm{c}$ & $128.1 \mathrm{c}$ \\
\hline $23 \mathrm{Kg} \mathrm{N} \mathrm{fed}^{-1}+2.5 \mathrm{t} \mathrm{RSC} \mathrm{fed}^{-1}$ & $95.31 \mathrm{~b}$ & $96.12 \mathrm{bc}$ & $23.67 \mathrm{~b}$ & $22.95 \mathrm{~b}$ & $172.8 \mathrm{~b}$ & $180.1 \mathrm{~b}$ \\
\hline $46 \mathrm{~kg} \mathrm{~N} \mathrm{fed}^{-1}+2.5 \mathrm{RSCfed}^{-1}$ & $96.86 \mathrm{~b}$ & $97.32 \mathrm{~b}$ & $26.95 \mathrm{a}$ & $26.87 \mathrm{a}$ & $197.7 \mathrm{a}$ & $195.2 \mathrm{a}$ \\
\hline
\end{tabular}

$\mathbf{R S C}^{*}=$ Rice straw compost, Means followed by the same letter are not significantly at the $5 \%$ level.

Dry matter accumulation increased significantly due to application of various different combinations in rice at all the growth stages of the crop over control. Also, dry matter increased with increasing plant age. The opposite was holding true with tillers since some of them was died at late growth stage. The highest dry matter accumulation was obtained when plants received $46 \mathrm{~kg} \mathrm{~N} \mathrm{fed}^{-1}+2.5 \mathrm{t}$ composted rice straw fed ${ }^{-1}$ at the three growth stages. Obviously, both application of 69 $\mathrm{kg} \mathrm{N}$ fed $^{-1}$ and $46 \mathrm{~kg} \mathrm{~N}_{\text {fed }}{ }^{-1}+2.5 \mathrm{t} \mathrm{RSCfed}^{-1}$ were comparatively in both seasons. Nitrogen application significantly increased chlorophyll content that resulted in high photosynthesis rate leading to high dry matter production. Similar findings are reported by Buri et al., (2004), Zayed et al., (2013), Gareib et al., (2015) and Metwaly, (2015)

Table 6: Some agronomic characteristics of EHR1 affected by rice straw compost, mineral N fertilizers and their combinations during 2013 and 2014 seasons.

\begin{tabular}{|l|c|c|c|c|c|c|}
\hline \multirow{2}{*}{ Treatments } & \multicolumn{2}{|c|}{$\begin{array}{c}\text { Panicle length } \\
(\mathbf{c m})\end{array}$} & \multicolumn{2}{c|}{$\begin{array}{c}\text { No. of } \\
\text { panicle hill }\end{array}$} & \multicolumn{2}{c|}{$\begin{array}{c}\text { Panicle weight } \\
\text { (g) }\end{array}$} \\
\cline { 2 - 7 } & $\mathbf{2 0 1 3}$ & $\mathbf{2 0 1 4}$ & $\mathbf{2 0 1 3}$ & $\mathbf{2 0 1 4}$ & $\mathbf{2 0 1 3}$ & $\mathbf{2 0 1 4}$ \\
\hline Control & $18.77 \mathrm{c}$ & $19.98 \mathrm{c}$ & $15.22 \mathrm{c}$ & $14.19 \mathrm{~d}$ & $2.77 \mathrm{c}$ & $2.91 \mathrm{c}$ \\
\hline $69 \mathrm{~kg} \mathrm{~N} \mathrm{fed}^{-1}$ & $24.12 \mathrm{a}$ & $24.21 \mathrm{a}$ & $25.17 \mathrm{a}$ & $27.18 \mathrm{a}$ & $4.18 \mathrm{a}$ & $4.35 \mathrm{a}$ \\
\hline $2.5 \mathrm{RSC}^{*} \mathrm{fed}^{-1}$ & $21.11 \mathrm{~b}$ & $22.32 \mathrm{~b}$ & $17.44 \mathrm{bc}$ & $16.55 \mathrm{~cd}$ & $3.36 \mathrm{~b}$ & $3.46 \mathrm{~b}$ \\
\hline $23 \mathrm{Kg} \mathrm{N} \mathrm{fed}^{-1}+2.5 \mathrm{RSC} \mathrm{fed}^{-1}$ & $21.74 \mathrm{~b}$ & $22.98 \mathrm{~b}$ & $19.33 \mathrm{~b}$ & $20.79 \mathrm{~b}$ & $3.58 \mathrm{~b}$ & $3.62 \mathrm{~b}$ \\
\hline $46 \mathrm{~kg} \mathrm{~N} \mathrm{fed}^{-1}+2.5 \mathrm{RSCfed}^{-1}$ & $24.43 \mathrm{a}$ & $24.57 \mathrm{a}$ & $24.98 \mathrm{a}$ & $24.20 \mathrm{ab}$ & $4.29 \mathrm{a}$ & $4.44 \mathrm{a}$ \\
\hline
\end{tabular}

$\mathbf{R S C}^{*}=$ Rice straw compost, Means followed by the same letter are not significantly at the $5 \%$ level.

Panicle weight was certainly affected by different fertilizer applications in both seasons. The adding rice straw compost, mineral $\mathrm{N}$ fertilizers and their combinations gave significant increase over control in which the heaviest panicles were recorded by $46 \mathrm{~kg} \mathrm{~N}$ $\mathrm{fed}^{-1}+2.5 \mathrm{t} \mathrm{RSCfed}^{-1}$ in both seasons (Table 6). Couple treatments of $46 \mathrm{~kg} \mathrm{~N}$ fed-1 + $2.5 \mathrm{t} \mathrm{RSCfed}^{-1}$ and $69 \mathrm{~kg}$ $\mathrm{N}$ fed ${ }^{-1}$ were identical regarding panicle weight in both seasons. An increment of panicle weight due to treatments might be primarily due to elevating chlorophyll concentration which led to higher photosynthetic rate and ultimately plenty of assimilates available during grain filling. Improving photosynthesis by RSC and nitrogen fertilizer application increased assimilate products at pre- and post-heading resulting in grain filling improvement and subsequently heavy panicles.

The average of both seasons indicated that the number of filled grains panicle ${ }^{-1}$ was significantly improved by the different fertilizer treatments. The application of $46 \mathrm{~kg} \mathrm{~N}$ fed $^{-1}+2.5 \mathrm{t}$ composted rice straw fed $^{-1}$ produced significantly higher number of filled

\section{A.2.Grain yield and yield attributing characteristics:}

Yield attributes i.e. panicle length $\mathrm{cm}$, number of panicles hill $^{-1}$, panicle weight, 1000-grain weight, number of filled grains panicle ${ }^{-1}$, as well as grain yield $t$ $\mathrm{fed}^{-1}$ are presented in Tables 6 and 7 . Adding $46 \mathrm{~kg} \mathrm{~N}$ fed-1 + 2.5 t RSC fed-1 harbored the tallest panicles without significant variation with $69 \mathrm{~kg} \mathrm{~N}^{\mathrm{N}} \mathrm{fe}^{-1}$ in both seasons. However, the shortest panicles were obtained with control treatment.

For number of panicles hill ${ }^{-1}$, the treatments of 69 $\mathrm{kg} \mathrm{N}$ fed $^{-1}$ produced the highest panicle numbers without significant differences with $46 \mathrm{~kg} \mathrm{~N}$ fed $^{-1}+2.5 \mathrm{t}$ $\mathrm{RSC} \mathrm{fed}^{-1}$ in both seasons. The lowest values of panicle hill $^{-1}$ were obtained when the plants were grown under control treatment (Table 6). grains panicle ${ }^{-1}$ than the other treatments (Table 7). Both treatments of $69 \mathrm{~kg} \mathrm{~N}^{-1}$ and $46 \mathrm{~kg} \mathrm{~N}$ fed-1 $+2.5 \mathrm{t}$ $\mathrm{RSC} \mathrm{fed}^{-1}$ were at a par in field grains panicle ${ }^{-1}$. The more number of filled grains panicle ${ }^{-1}$ was probably due to better nitrogen status of plant during panicle growth period.

Regarding to 1000-grain weight, the highest value of 1000- grain weight was obtained when rice plants were fertilized by $69 \mathrm{~kg} \mathrm{~N}^{-1} \mathrm{fed}^{-1}$ followed by 46 $\mathrm{kg} \mathrm{N}$ fed $^{-1}+2.5 \mathrm{t}$ composted rice straw RSC fed ${ }^{-1}$ combination. The control treatment gave the lowest value of this trait (Table 7). Improvement of 1000-grain weight might be mainly due to improving rice grain filling resulted in heavy grains.

Data in Table 7 showed that grain yield was affected by combinations of fertilizer treatment in both seasons. There were significant increases in grain yield with applying different fertilizers as compared with control treatment. However, applying $69 \mathrm{~kg} \mathrm{~N}^{-1}$ produced maximum grain yield $\mathrm{fed}^{-1}$ followed by $46 \mathrm{~kg}$ $\mathrm{N} \mathrm{fed}+2.5 \mathrm{t} \mathrm{fed}^{-1} \mathrm{RSC}$ in both seasons (Table 7). As it is recognized in table 7 , couple treatments of $46 \mathrm{~kg}$ 
$\mathrm{Nfed}^{-1}+2.5 \mathrm{t} \mathrm{fed}^{-1} \mathrm{RSC}$ were comparatively in both seasons. Interestingly, $69 \mathrm{~kg} \mathrm{~N} \mathrm{fed}^{-1}$ produced maximum grain yield/fed followed by $2.5 \mathrm{t}$ fed-1 RSC $+46 \mathrm{~kg} \mathrm{~N}$ $\mathrm{fed}^{-1}$ apparently saving one third of mineral recommended nitrogen fertilizer without significant yield reduction. However, Egyptian hybrid rice 1 rice variety is adequately stable concerning its genetic potential for grain yield. Finally, there was a close link between yield and its components, especially with number of filled grains per panicle. The improved growth attributes, viz plant height, chlorophyll content and dry-matter production might be responsible for improved yield attributes .

The benefit of rice straw compost might be attributed to its affinity to increase NPK availability and organic matter of soil content, which is deficient in saline soils. Rice straw compost can play an effective role, improving soil properties, and fertility maintenance. In addition, rice straw compost has the potential to enrich soils with $\mathrm{K}^{+1}$ and $\mathrm{Si}^{+2}$. It is obvious that there is a good synergy between organic fertilizer and application of two-thirds of the recommended nitrogen rate, particularly with rice straw compost. It was recognized that application of nitrogen improves various crop parameters like panicle length, more productive tillers, number of filled grains per panicle and 1000-grain weight thus resulting in higher yields. Similar finding were reported by Man et al. (2009), Zayed et al. (2013), Malav and Ramani (2015) and Metwally (2015).

Table 7: Some yield components and grain yield of EHR1as affected rice straw compost, mineral N fertilizers and their combinations during 2013 and 2014 seasons.

\begin{tabular}{|l|c|c|c|c|c|c|}
\hline \multirow{2}{*}{ Treatments } & \multicolumn{2}{|c|}{$\begin{array}{c}\text { No of filled } \\
\text { grains/ panicle }\end{array}$} & \multicolumn{2}{|c|}{$\begin{array}{c}\text { 1000 grain weight } \\
\text { (g) }\end{array}$} & \multicolumn{2}{c|}{$\begin{array}{c}\text { Grain yield } \\
\text { t fed. }\end{array}$} \\
\cline { 2 - 7 } & $\mathbf{2 0 1 3}$ & $\mathbf{2 0 1 4}$ & $\mathbf{2 0 1 3}$ & $\mathbf{2 0 1 4}$ & $\mathbf{2 0 1 3}$ & $\mathbf{2 0 1 4}$ \\
\hline Control & $117.10 \mathrm{~d}$ & $116.30 \mathrm{c}$ & $20.66 \mathrm{c}$ & $20.96 \mathrm{c}$ & $3.27 \mathrm{~d}$ & $3.11 \mathrm{~d}$ \\
\hline 69 kg N fed-1 & $183.50 \mathrm{a}$ & $185.80 \mathrm{a}$ & $23.99 \mathrm{ab}$ & $23.97 \mathrm{a}$ & $5.39 \mathrm{a}$ & $5.36 \mathrm{a}$ \\
\hline $2.5 \mathrm{t}$ RSC* fed-1 & $163.20 \mathrm{c}$ & $160.80 \mathrm{~b}$ & $21.24 \mathrm{bc}$ & $21.18 \mathrm{bc}$ & $3.83 \mathrm{c}$ & $4.02 \mathrm{c}$ \\
\hline 23 Kg N fed-1 + 2.5 t RSC fed-1 & $183.20 \mathrm{~b}$ & $185.10 \mathrm{~b}$ & $22.66 \mathrm{~b}$ & $21.98 \mathrm{~b}$ & $4.99 \mathrm{~b}$ & $4.92 \mathrm{~b}$ \\
\hline 46 kg N fed-1+2.5 t RSC fed-1 & $195.60 \mathrm{a}$ & $191.20 \mathrm{a}$ & $23.96 \mathrm{a}$ & $23.91 \mathrm{a}$ & $5.36 \mathrm{a}$ & $5.23 \mathrm{a}$ \\
\hline
\end{tabular}

RSC $^{*}=$ Rice straw compost, Means followed by the same letter are not significantly at the $5 \%$ a level.

\section{B. plant diseases}

\section{B.1 White head percentage:}

Data in Table 8 showed that White head percentage has been affected by using different types of fertilizers. Rice plots fertilized with mineral nitrogen only had the highest levels of white heads. On the other hand, the lowest values of white head \% were recorded when rice plants were fertilized with $2.5 \mathrm{RSC} \mathrm{t} \mathrm{fed}^{-1}$ in both seasons (Table 8). The applications of sole composted rice straw reduce stem borer infestations; 7.77 and $6.93 \%$ white head in the first and second seasons, respectively. The low rice stem borer infestation in plots treated with composted rice could be attributed to the role of silica in controlling the rice stem borer. In such concern, Djamin and pathak (1967) found that the incisor region of the mandibles of stem borer larvae fed on rice plants with high $\mathrm{Si}^{+}$content were more damaged. Chandraman et al., (2010) and Malav and Ramani (2015) recorded a significant negative correlation between insect incidence (from which is the rice stem borer) and rice plant content of silica.

\section{B.2. Leaf miner infestation}

The rice leaf miner infestation was lowest in case of control treatment, 16.00-16.33\% infested leaves, and 37.00- $43.67 \%$ mines/100 leaves (Table9). All treatments, mineral fertilizers, mineral combined with compost, compost only had no significant difference on rice leaf miner infestation.

Most of reports suggested that fertilization had no effect on rice leaf minor damage to rice plants. Nitrogen levels up to $160 \mathrm{~kg} / \mathrm{ha}$ had no effect on the number of rice whorl maggot eggs on rice plants (IRRI 1983). In Egypt, El-Metwally (1977) and Sherif et al (1997) tested the effect of nitrogen, phosphorous and potassium combinations on $H$. prosternalis damage in rice fields. They found that fertilizers had no effect on the infestation by this insect.

Table 8: Population of white heads of EHR1 affect by compost, mineral nitrogen fertilizers and their combinations during 2013 and 2014 seasons

\begin{tabular}{|l|c|c|c|c|}
\hline \multirow{2}{*}{ Treatments } & \multicolumn{2}{|c|}{ White head\% } & \multicolumn{2}{c|}{ Reduction\% } \\
\cline { 2 - 5 } & $\mathbf{2 0 1 3}$ & $\mathbf{2 0 1 4}$ & $\mathbf{2 0 1 3}$ & $\mathbf{2 0 1 4}$ \\
\hline Control & $12.73 \mathrm{ab}$ & $11.55 \mathrm{a}$ & 5.35 & 7.67 \\
\hline $69 \mathrm{~kg} \mathrm{~N} \mathrm{fed}^{-1}$ & $13.45 \mathrm{a}$ & $12.51 \mathrm{a}$ & - & - \\
\hline $2.5 \mathrm{t} \mathrm{RSC}^{*} \mathrm{fed}^{-1}$ & $7.77 \mathrm{c}$ & $6.93 \mathrm{c}$ & 38.96 & 44.6 \\
\hline $23 \mathrm{Kg} \mathrm{N} \mathrm{fed}^{-1}+2.5 \mathrm{t} \mathrm{RSC} \mathrm{fed}^{-1}$ & $10.19 \mathrm{bc}$ & $9.98 \mathrm{~b}$ & 24.24 & 20.22 \\
\hline $46 \mathrm{~kg} \mathrm{~N} \mathrm{fed}^{-1}+2.5 \mathrm{RSC} \mathrm{fed}^{-1}$ & $12.21 \mathrm{ab}$ & $11.64 \mathrm{a}$ & 9.22 & 6.95 \\
\hline
\end{tabular}

RSC $^{*}=$ Rice straw compost, Means followed by the same letter are not significantly at the $5 \%$ level. 
Table 9: leaf miner infestation of EHR1 affected by compost, mineral nitrogen fertilizers and their combinations fields during 2013 and 2014 seasons.

\begin{tabular}{|l|c|c|c|c|}
\hline \multirow{2}{*}{ Treatments } & \multicolumn{2}{|c|}{ Infested leaves\% } & \multicolumn{3}{c|}{ Mines/100 leaves } \\
\cline { 2 - 5 } & $\mathbf{2 0 1 3}$ & $\mathbf{2 0 1 4}$ & $\mathbf{2 0 1 3}$ & $\mathbf{2 0 1 4}$ \\
\hline Control & 16.00 & 16.33 & 43.67 & 37.00 \\
\hline $69 \mathrm{~kg} \mathrm{~N} \mathrm{fed}^{-1}$ & 32.33 & 31.00 & 53.33 & 50.67 \\
\hline $2.5 \mathrm{t} \mathrm{RSC}^{*} \mathrm{fed}^{-1}$ & 25.67 & 23.00 & 40.67 & 38.67 \\
\hline $23 \mathrm{Kg} \mathrm{N} \mathrm{fed}^{-1}+2.5 \mathrm{t} \mathrm{RSC} \mathrm{fed}^{-1}$ & 28.33 & 26.67 & 44.67 & 42.33 \\
\hline $46 \mathrm{~kg} \mathrm{~N} \mathrm{fed}^{-1}+2.5 \mathrm{t} \mathrm{RSC} \mathrm{fed}^{-1}$ & 29.67 & 27.33 & 43.67 & 41 \\
\hline
\end{tabular}

RSC $^{*}=$ Rice straw compost, Means followed by the same letter are not significantly at the $5 \%$ level.

\section{B.3.Sheath rot disease infection}

Sheath rot disease infection percentage was markedly affected by using different types of fertilizers. Rice plots fertilized with mineral urea-nitrogen had the highest levels of Infection 3.41, 3.16\% (in $69 \mathrm{~kg} \mathrm{~N}$ fed $^{1}$ ), 3.62, $2.86 \%$ (in $46 \mathrm{~kg} \mathrm{~N}^{-1} \mathrm{~d}^{-1}+2.5 \mathrm{t}$ composted rice straw fed-) in both rice seasons, respectively. The applications of sole composted rice straw reduced sheath rot disease infection percentage alone or mixed with $23 \mathrm{Kg} \mathrm{N} \mathrm{fed}^{-1}$ in the first and second seasons (Table 10). The highest infection percentage was correlated with high rate of nitrogen fertilization. These results are in accordance with Krauss (2000) who reported that plants excessively supplied with nitrogen have soft tissue with little resistance to penetration by fungal hyphae or sucking and chewing insects. The lower sheath rot infection percentage in treatment with composted rice could be attributed to the role of silica in controlling the rice diseases generally. The mechanism of resistance in rice due to $\mathrm{Si}$ application has been attributed to the formation of a silicate epidermal cell wall layers (Takahashi; 1965 and Yoshida, 1975). This layer is believed to prevent physical fungal penetration and makes the plant cell walls less susceptible to enzymatic degradation by fungal pathogens. Rapid deposition of phenols or lignin at the infection site is a known general defense mechanism of plants attacked by pathogens and the presence of soluble Si may facilitate this mechanism of resistance in rice.

Table 10: Sheath rot disease infection of EHR1 affected by rice straw compost, mineral N fertilizers and their combination during 2013 and 2014 seasons.

\begin{tabular}{|l|c|c|}
\hline \multirow{2}{*}{ Treatments } & \multicolumn{2}{|c|}{ Infection\% } \\
\cline { 2 - 3 } & $\mathbf{2 0 1 3}$ & $\mathbf{2 0 1 4}$ \\
\hline Control & $2.8100 \mathrm{~b}$ & $2.9967 \mathrm{a}$ \\
\hline $69 \mathrm{~kg} \mathrm{~N} \mathrm{fed}^{-1}$ & $3.4133 \mathrm{a}$ & $3.1600 \mathrm{a}$ \\
\hline $2.5 \mathrm{RSC}^{*} \mathrm{fed}^{-1}$ & $2.1467 \mathrm{c}$ & $2.2300 \mathrm{~b}$ \\
\hline $23 \mathrm{Kg} \mathrm{N} \mathrm{fed}^{-1}+2.5 \mathrm{RSC} \mathrm{fed}^{-1}$ & $2.3667 \mathrm{c}$ & $2.1567 \mathrm{bc}$ \\
\hline $46 \mathrm{~kg} \mathrm{~N} \mathrm{fed}^{-1}+2.5 \mathrm{rSC} \mathrm{fed}^{-1}$ & $3.6200 \mathrm{a}$ & $2.8667 \mathrm{ab}$ \\
\hline
\end{tabular}

RSC $^{*}=$ Rice straw compost, Means followed by the same letter are not significantly at the $5 \%$ level.

\section{Economic evaluation}

Data in Table 11 showed that treatment of $69 \mathrm{~kg}$ $\mathrm{Nfed}^{-1}$ had the highest values of revenue $1 \mathrm{E} \mathrm{fed}$ followed by the treatment of $46 \mathrm{~kg} \mathrm{~N}_{\mathrm{Ned}}^{-1}+2.5 \mathrm{t} \mathrm{fed}^{-1}$ RSC. On the other hand, the lowest values of revenue were produced by control treatment followed by the treatment of $2.5 \mathrm{t} \mathrm{fed}^{-1} \mathrm{RSC}$ both seasons. Furthermore, the control treatment recorded the minimum values of total production cost followed by the treatment of $69 \mathrm{~kg}$ $\mathrm{N} \mathrm{fed}{ }^{-1}$. The treatment of $46 \mathrm{~kg} \mathrm{~N} \mathrm{fed}^{-1}$ had higher costs. The control treatment recorded the minimum net return in both seasons. The highest net return was obtained by applying $69 \mathrm{~kg} \mathrm{~N} \mathrm{fed}{ }^{-1}$ followed by treatment of $46 \mathrm{~kg} \mathrm{~N} \mathrm{fed}^{-1}+2.5 \mathrm{t} \mathrm{fed}^{-1}$.

Table 11: Economic evaluation of EHR1 affected by rice straw compost, mineral N fertilizers and their combination during 2013 and 2014 seasons.

\begin{tabular}{|c|c|c|c|c|c|c|c|c|c|c|}
\hline \multirow[t]{2}{*}{ Treatments } & \multicolumn{2}{|c|}{$\begin{array}{l}\text { Revenue } \\
\text { LE fed }^{-1}\end{array}$} & \multicolumn{2}{|c|}{$\begin{array}{c}\text { Variable } \\
\text { cost } \\
\text { LE fed }^{-1}\end{array}$} & \multicolumn{2}{|c|}{$\begin{array}{c}\text { Fixed and } \\
\text { operational cost } \\
\text { LE fed }^{-1}\end{array}$} & \multicolumn{2}{|c|}{$\begin{array}{c}\text { Total } \\
\text { production cost }^{\text {LE fed }^{-1}}\end{array}$} & \multicolumn{2}{|c|}{$\begin{array}{l}\text { Net return } \\
\text { LE fed }\end{array}$} \\
\hline & 2013 & 2014 & 2013 & 2014 & 2013 & 2014 & 2013 & 2014 & 2013 & 2014 \\
\hline Control & 5880.6 & 5603.4 & 0 & 0 & 2.100 & 2.100 & 2.100 & 2.100 & 3570.6 & 3293.4 \\
\hline 69 kg N fed-1 & 9702 & 9642.6 & 450 & 420 & 2.260 & 2.290 & 2.710 & 2.740 & 6721 & 6628.6 \\
\hline 2.5 t RSC $*$ fed-1 & 6890.4 & 7227 & 500 & 500 & 2.140 & 2.150 & 2.640 & 2.650 & 3986.4 & 4312 \\
\hline $23 \mathrm{Kg} \mathrm{N}$ fed-1 + $2.5 \mathrm{t} \mathrm{RS}$ & 8937.5 & 8850.6 & 650 & 640 & 2.140 & 2.150 & 2.790 & 2.790 & 5868.5 & 5781.6 \\
\hline $46 \mathrm{~kg} \mathrm{~N}$ fed-1 + 2.5 t RSC fed-1 & 9642.6 & 9405 & 800 & 780 & Y.I & r.IV. & Y.9ะ. & 1.90. & 6441.6 & 6160 \\
\hline
\end{tabular}

Average paddy rice price from Oct 2012 to Oct 2013=1800LE/metric ton.150 and $140 \mathrm{LE} / 50 \mathrm{~kg}$ urea in 2013 and $2014 \mathrm{seasons}$, resp.

\section{CONCLUSION}

It could be concluded that utilization of $46 \mathrm{~kg} \mathrm{~N}$ fed $^{-1}$ in combination with $2.5 \mathrm{t}$ composted rice straw fed $^{-1}$ is more favorable, most efficient and best economic way for rice production under the present experimental conditions for increase rice grain yield and maintain the soil fertility. However, to diminish 
chemical fertilizer in rice without reduction in grain yield, utilization of $2.5 \mathrm{t}$ composted rice straw fed ${ }^{-1}$ plus $46 \mathrm{~kg} \mathrm{~N}$ fed $^{-1}$ could be applied.

\section{Acknowledgements}

The author sincerely thank Drs Ahmed Hendawy and Rabab Elamawi Rice research and training center for their help to collecting data concerning some rice pests.

\section{REFERENCES}

Buri, M.M.; R.N. Issaka; T. Wakatsuki and E. Otoo (2004). Soil organic amendments and mineral fertilizers: options for sustainable lowland rice production in the forest agro-ecology of Ghana. Agric. \& Food Sci. J. of Ghana 3: 237-248.

Chandramani P.; R. Rajendran1; C. Muthiah and C. Chinniah (2010). Organic source induced silica on leaf folder, stem borer and gall midge population and rice yield. J. of Biopesticides, 3(2): $423-427$.

Croft, B. A. (1990). Arthropod biological control agents and pesticides. Wiley and Sons, New York .

Djamin, A. and Pathak M. D. (1967). Role of silica in resistance to Asian rice borer, Chilo suppressallis (Walker), in rice varieties. J. Econ, Entomol., 60: 347-351.

Duncan, D. B. (1955). Multiple Ranges and Multiple F Test. Biometrics, 11: 1-42.

El-Metwally, E.F. (1977). Biological and ecological studies on the rice leaf-miner, Hydrellia prosternalis Deeming (Diptera: Ephydridae). M.Sc. Thesis, Fac. of Agric., Cairo Univ.

IRRI (1983). International Rice Research Institute Annual Report for 1982, Los Banos, Philippines. (47): 198-199

Gharieb, A. S.; T. F. Metwally; S.H. Abou-Khadrah and A. A. Glelah ( 2015). Rice soil properties and nutrients uptake as affected by compost and antioxidant application. Inte. J. of ChemTech Res., 8(4): 1543-1556.

Gomez, K.A. and A.A. Gomez (1984). Statistical procedures for agricultural research. $2^{\text {nd }} E d$. John Wiley and Sons, New York, USA.

Gotoh, S; H. Koga and S.I. Ono (1984). Effect of longterm application of organic residues on the distribution of organic matter and nitrogen in some rice soil profiles. Soil Sci. and Plant-Nutr., 30(3):273-285.

Heckman, J. (2006). A history of organic farming: Transitions from Sir Albert Howard's war in the soil to USDA National Organic Program. Renewable Agri. and Food Syst. 21:143-150.

Krauss, A. (2000). Potassium, integral part for sustained soil fertility In: Proc. Regional IPI Workshop on Potassium and phosphorus fertilization effect on soil and crop, 23-24 October, 2000 DotnuvaAkademija, Lithuania.

Man, L.H.; V.T. Khang and T. Watanabe (2009). Improvement of soil fertility by rice straw manure. Omonrice 16: 71-80 .
Malav, J. K. and V. P. Ramani (2015). Effect of Silicon and Nitrogen on major pest and disease intensity in low land rice. African J. of Agric. Res., 10(33):3234-3238.

Marub, F. (1993). YRSB eggs parasitoid potential to different rice varieties in an IPM. Ilum Pertania, 5 (3): $645-656$.

Metwally, T.F; E.E.Gewaily; E.S. Naeem and M. M. ElMalky (2011). Response of different promising rice genotypes to various nitrogen levels. J. Agric. Sci. Mansoura Univ., 2 (43): 507 - 520

Metwally T.F. (2015). Impact of organic materials combined with mineral nitrogen on rice growth, Yield, Grain Quality and Soil Organic Matter. Inte. J. of ChemTech Res. 8(4):1533 - 1542.

Mona, M.S. (2012). Studies on the sheath rot disease of rice. Kafrelsheikh Univ. Egypt, Ph.D. thesis

Nyalemegbe, K.K.; J.W. Oteng, S.A. Brempong (2009). Integrated organic-inorganic fertilizer management for rice production on the Vertisols of the Accra Plains of Ghana. West African J. of Applied Ecology 16: 23-32.

Nurullah, C.M. (1979). Component analysis for the integrated control of rice whorl maggot, Hydrellia sasakii Yusaa and Isitani. M.Sc. Thesis, Univ. of Philippines, Los Banos, 120 pp..

Ou, S.H. (1985). Rice Diseases. 2nd ed. Common wealth Mycological Institute, Kew, England, pp380.

Pekar, S. (2012). Spiders (Araneae) in the pesticide world: an ecotoxicological review. Pest Manage. Sci., 68: 1438 -1446.

Sherif, M.R; A.S. Hendawy and M.M. El-Habashy (2005). Management of rice insect pests, Egypt. J. Agric. Res., 83 (5a):111-130

Sherif, M.R.; I. Khodeir and M. El-Habashy (1997). Cultural practices to manage the rice leafminer, Hydrellia prosternalis (Diptera: Ephydridae) in Egypt. Egypt. J. Agric. Res., 75(3): 611-622.

Takahashi, E. (1965). Uptake mode and physiological functions of silica. Sci. Rice Plants, 2:58-71.

Thapak, S.K.; V.S. Thrimurty, and R.K. Dantre, (2003). Sheath rot management in rice with fungicides and biopesticides. IRRN, 28(1):41.

Yoshida, S. (1975). The physiology of silicon in rice. Technical Bulletin N. 25. Food fret. Technical Center. Taipei. Taiwa.

Yoshida, S., Forno, D.A., Cock, J.H. \&Gomez, K.A.(1976). Laboratory manual for physiology studies of rice .IRRI, Los banos, Philippines.

YungYu, C. (2005). Effect of application of different types of organic compost on rice growth under laboratory conditions. Soil Sci. and Plant Nutr., 51(3):443-449.

Zayed, B.A.; W. M. Elkhoby; A.K. Salem; M. Ceesay and N.T. Uphoff (2013) Effect of integrated nitrogen fertilizer on rice productivity and soil fertility under saline Soil conditions. J. of Plant Biology Res., 2013, 2(1): 14-24. 
Elkhoby, W. M.

تاثير كمبوست قش الارز مع النتروجين المعدني علي انتاجية الارز الهجين مصري واحد وبعض افات الأرز وليا محمد حسين الخبي قسم بحوث الأرز- معهز بحوث الخدي محاصيل الحقلية ـمركز البحوث الزراعيةـ مصر

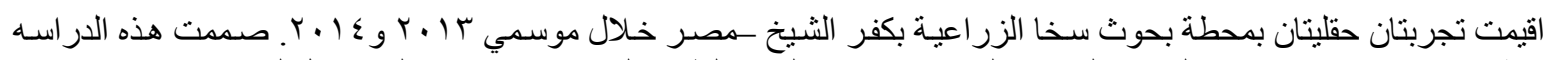

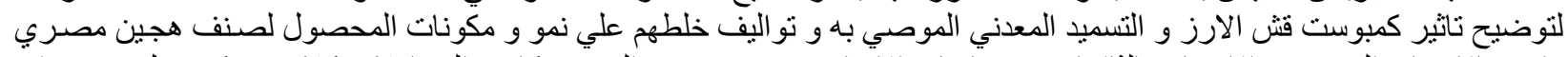

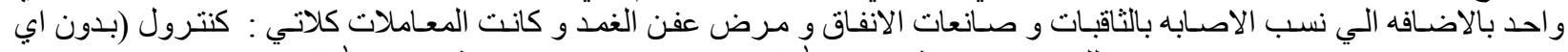

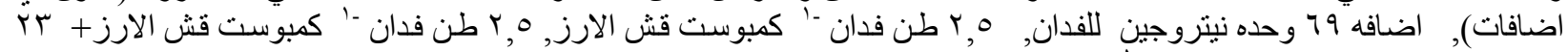

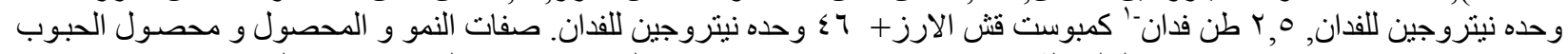

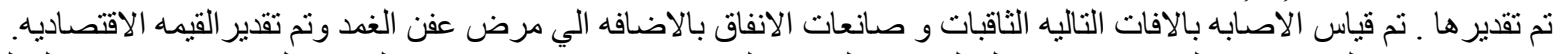

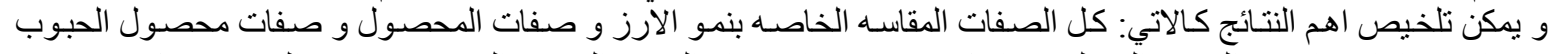

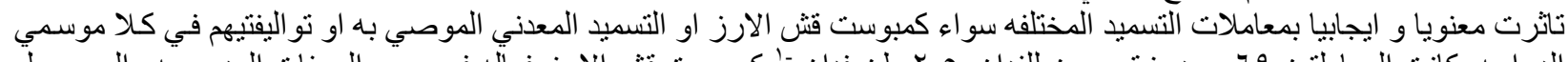

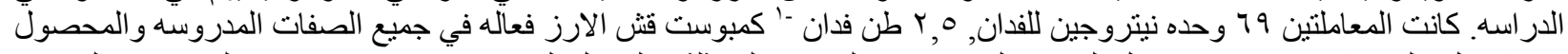

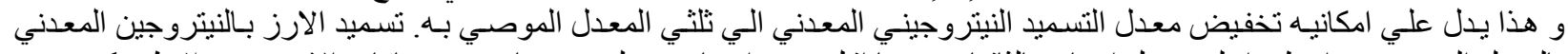

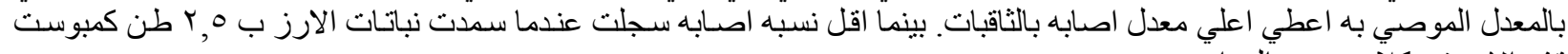

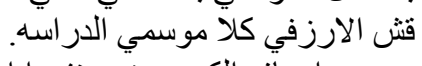

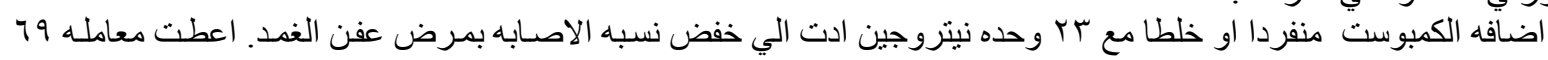

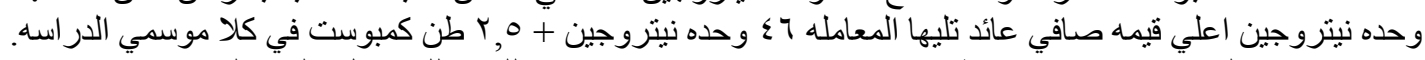

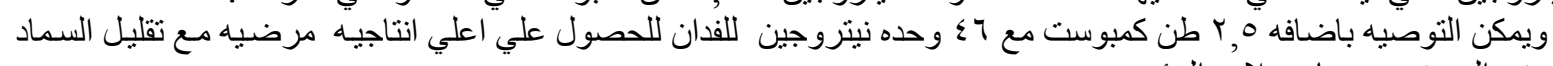

النيتروجيني المعدني وضنمان سلامهـ البيئه. 